\title{
Interleukin-10, Interleukin- 16 and Interferon- $\gamma$ in serum of patients with rheumatoid arthritis and correlation with disease activity
}

\author{
Eman.M.Abdel Rahman, Hamdia.Ezzat, Maha M Abdel Mohsen, \\ Karema Yosef
}

Clinical pathology\& Internal Medicine Departments, Faculty of Medicine for girls, Al Azhar University

\section{Abstract}

Rheumatoid arthritis (RA) is a systemic inflammatory disease of unknown etiology. The rheumatoid synovium is characterized by infiltration of $\mathrm{T}$ cells, macrophage, $\mathrm{B}$ cells, and proliferating fibroblasts which aggressively invade cartilage and bone, thus destroying joints' ability to function.

In rheumatoid arthritis (RA) both an imbalance between excessive production of the proinflamatory and ant-inflammatory cytokines and skewing of the $\mathrm{T}$ cell to a $\mathrm{T}$ helper like response.

Cytokines have been shown to play a modulatory role in the pathogenesis of RA. The imunoregulatory cytokine IL-10 increases autoantibody production by B cell stimulates its survival, proliferation and differentiation. Moreover IL-10 inhibits the generation of proinflamatory cytokines and proliferation of $\mathrm{T}$ helper lymphocyte.

Interleukin 16 might play a role in the pathogenesis of chronic inflammation in RA. It has a proinflammatory properties by promoting recruitment of $\mathrm{T}$ cells into the rheumatoid synovium. Also IFN- $\gamma$ is of interest because of the role it plays in the initiation and perpetuation of $\mathrm{T}$ helper cell .

Serum level of IL-10, IL-16, and IFN- $\gamma$ were determined in patients with rheumatoid arthritis in relation to disease activity.

All patients with RA ( $\mathrm{n}=30$ ) showed highly significant increase in ESR, CRP, IL-10, IL16 , IFN $\gamma$ compared to control group $(\mathrm{p}<0.01)$.

Positive correlation were found between IL-10 and each IL-16 and IFN- $\gamma(\mathrm{p}<0.001)$ $(\mathrm{r}=0.63,0.55)$ respectively, and highly significant correlation between IL-16 and IFN $\gamma$ $(\mathrm{p}<0.001)(\mathrm{r}=0.89)$ were determined.

Results showed positive correlation between ESR and each IL-10, IL-16, IFN $\gamma(\mathrm{p}<0.001)$ $(\mathrm{r}=0.67,0.87,0.75)$ respectively. And highly significant correlation between CRP and each IL10, IL-16, IFN $\gamma(\mathrm{p}<0.001)(\mathrm{r}=0.0 .71,0.83,0.73)$ which indicate relation between increase level of cytokine with disease activity.

These data suggest that there is increased production of IL-10, IL-16, and IFN- $\gamma$ in patients with rheumatoid arthritis, and that it is correlated with the disease activity. These cytokines are interesting for further research and novel therapeutic approach in this inflammatory disease.

\section{Introduction}

Rheumatoid arthritis (RA) is inflammatory disease of unknown etiology chara-cterized by destruction of joints (Verhoef et $a l ; 2001)$. Activation and infiltration of immunologic cells, including macrophage and lymphocytes, are prominent features of chronic inflammation in rheumatoid arthritis (Scola et al;2002).
In RA, the cytokines resulting from this cellular infiltration greatly influence the outcome of disease. Macrophage generally express higher levels of cytokines than lymphocyte in RA, while the lymphocyte contribution to inflammatory and/or joint destructive process may be more indirect (Panayi et al;1992). 
Two subsets of $\mathrm{T}$ cells are recognized by their ability to produce different types of cytokines. Th1 cell activity characterized by IFN- $\gamma$ production participates in macrophage activation and thereby causes joint destruction (Verhoef et al;2001)

Th2 cells selectively produces IL-4, IL-5, IL-6, IL-10 and IL-13, these cytokines mediate transformation of B- lymphocytes into antibody producing plasma cells (Libula et al;1995). The balance between T1 and $\mathrm{T} 2$ cells regulates the production of pro- and anti-inflammatory cytokines (Verhoef et al;2001)

Systemic clinical signs of rheumatoid, such as the acute phase response (ESR, and $\mathrm{CRP}$ ) in turn depend on the balance between these pro- and anti-inflammatory cytokines (Littman et al;1995).

Interleukin-10(IL-10) one of the cytokines which had been shown to exert a number of immunoregulatory and antiinflammatory effect in RA (Cush et al;1995). The immunoregulatory cytokine IL-10 increases autoantibody production by B cells from RA patients (Reparon-Schujt et al;1998 and 2001)).

A side from this immunostimulatory function, IL-10 inhibits the activation and effectors functions of $\mathrm{T}$ cells, macrophage, and monocytes (Lard et al;2003). As an anti-inflammatory cytokine IL-10 has been shown to inhibit the synthesis of IL-1 $\alpha$, IL$1 \mathrm{~B}$, and TNF- $\alpha$, IL-6, IL-8, IL-12, and IL18. IL-10 also inhibits the synthesis of gelatinase and collagenase (Oberholzer et $a l ; 2002)$.

Interleukin -16 (IL-16) also known as lymphocyte chemoattractant factor, is generally considered to play a decisive role in most immune and inflammatory responses (Kaufmann et al;2001) in rheumatoid arthritis the presence of IL-16 has been described in synovial tissues from patients with RA. However the functional activity of this $\mathrm{T}$ cell derived cytokine in the pathogenesis of RA is not completely understood (Blaschke et al;2001).

Interferon- gamma (IFN- $\gamma$ ) is a secretary product of activated T-cell of the Th1 subset and natural killer cells (NK). INF- $\gamma$ is produced in response to specific and non-specific immunologic activation of lymphocyte, usually T-lymphocytes (Boehm et al;1997). IFN- $\gamma$ can down-regulate parameters of joint destruction such as IL-1, matrix metalloproteinase and proliferation of fibroblast- like synoviocytes (FLS) (Moller et al;2003).

\section{Aim of the work}

Is to determine the level of IL-10, IL16 , and IFN $\gamma$ in serum of patients with rheumatoid arthritis and assessing their role with disease activity.

\section{Patients and methods \\ Subjects:}

Our study included 30 patients with rheumatoid arthritis and 10 healthy controls. All patients were selected from patients attending internal medicine department, Al Zahraa university hospital

Subjects were divided into 2 groups:

Group I: (RA group): 30 patients were fulfilling The 1988 Revised American Rheumatism Association (ARA) criteria for adults RA (Arnett, et al 1988)) 22 were female and 8 were males.

Their Age ranged from 17-50 years with a mean of $(28.3 \pm 9.7)$.

Duration of disease ranged between 2.5 and 9 years with mean $(5.2 \pm 2)$.

Morning stiffness ranged between 18 and 90 minute, with mean $(19 \pm 2)$.

Articular index score (AIS) ranged between 22 and 27 with mean $(24.8 \pm$ 1.7)

Group II: (Control group): 10 healthy age and sex matched volunteers; they were selected from medical and paramedical staff of the hospital, 2 males and 8 females. Their Age ranged between 1951 years with mean $(31.7 \pm 9.7)$.

\section{All patients and controls were submitted} to the following:

1- Complete history taking and full clinical examination

2-Routine laboratory investigations including:

- Complete blood picture by automated blood counter.

- Assessment of ESR in the first hour according to Westergen method (1921) 
- Latex rheumatoid factor

- C-reactive protein (CRP level)

- Fasting blood sugar, liver function tests and kidney function tests, using Bohringer Mannheim Company photometric kits West Germany on Hitachi 911 auto analyzer.

3- Specific laboratory investigations including:

1. Serum IL-10 by ELISA

(II) Serum IL-16 by ELISA

2. Serum INF- $\gamma$ by ELISA

- For this purpose blood samples from patients and control were taken at the morning to avoid the influence of the time of the day on lymphocyte responses and cytokines. About $5 \mathrm{cc}$ of venous blood was drawn and centrifuged for about 10 minutes and serum was separated, taken and stored at $-20 \mathrm{c}^{\circ}$ until time of analysis.

Cytokines concentration were measured in serum using a commercially available monoclonal antibody based sandwich ELISA kit (Biosourse Europe S.A) for human IL-10,IL-16 and INF- $\gamma$. Briefly, standards, samples, and controls tested sera were pipetted into wells precoated with murin monoclonal antibodies raised against each parameter followed by addition of horse radish peroxidase antibodies to each parameter. After an incubation period allowing the formation of a sandwich, coated Mab1+Mab2 HRP.

The microtiter plate was washed to remove unbound enzyme labeled antibodies. Bound enzyme labeled antibodies were measured through a chromogenic reaction. Chromogenic solution (TMB+ $\mathrm{H} 2 \mathrm{O} 2$ ) was added and incubated. The reaction stopped with the addition of stop solution(H2SO4) and the microtiter plate was then read at $450 \mathrm{~nm}$ wave length. The level of IL-10, IL-16 and INF $\gamma$ were calculated from standard curve corresponding to the measured optical densities. The results expressed as $\mathrm{pg} / \mathrm{ml}$.

All RA patients met the American College of Rheumatology (ACR) 1987 revised criteria for the classification of RA (Arnett et al; 1988). The disease activity comprised assessment of morning stiffness
(MS) duration in minutes, articular index scor (AIS) (joint tenderness) it is measured using The Ritchia articular index (Ritichia, et al, 1968), ESR in the first hours hemoglobin percentage $(\mathrm{Hb} \%)$ and radiological examination of the affected joints.

\section{Statistical analysis}

Results were tabulated and statistically analyzed through Compaq computer. The value were given as mean \pm SD. Comparison of the values were performed using the unpaired student $\mathrm{T}$ test and one tailed $\mathrm{P}$ value is considered significant when it is $<0.05$.

\section{Results}

Baseline clinical and laboratory characteristic of the studied groups is provided in table(1).

Table (1) show the criteria of RA (Age, duration of disease, morning stiff, tender joint, swollen joint count, articular index score (AIS).

Table(2) and fig(1,2,3) show that There was highly significant increase in ESR, CRP in patients with RA compared to control group $(\mathrm{P}<0.001)$.Also there was highly significant increase in serum IL-10, IL-16, IFN $\gamma$ in patients with RA compared to control group $(\mathrm{P}<0.001)$.

Table (3) shows correlation between serum IL-10 and each $\mathrm{Hb}$, ESR, CRP, IL16 , IFN $\gamma$ in group I (30 patients with RA). There was highly significant correlation between S. IL10 and each of ESR, CRP, IL16, IFN $\gamma(\mathrm{p}=<0.001)(\mathrm{r}=0.67,0.71,0.63$, $0.55)$ respectively. Also there was negative significant correlation between S.IL-10 and $\mathrm{Hb} \quad(\mathrm{p}=<0.001) \quad(\mathrm{r}=0.74)$. Fig 4 show positive correlation between IL-10 and IL16 among group 1.

Fig 5 show positive correlation between IL-10 and IFN $\gamma$ among group 1

Table (4) show correlation between serum IL-16 and each Hb, ESR, CRP, IFN $\gamma$ in group I (30 patients with RA). There was highly significant correlation between $\mathrm{S}$. IL16 and each of ESR, CRP, IFN $\gamma$ $(\mathrm{p}=<0.001) \quad(\mathrm{r}=0.87,0.83,0.89$,$) respect-$ ively. Also there was negative significant 
correlation between S.IL-16 and $\mathrm{Hb}$ $(\mathrm{p}=<0.001)(\mathrm{r}=0.89)$.

Fig 6 show positive correlation between IL-16 and IFN $\gamma$ among group 1.

Table (5) show correlation between serums IFN $\gamma$ and each $\mathrm{Hb}$, ESR, CRP, in group I (30 patients with RA). There was highly significant correlation between IFN $\gamma$ and each of ESR, CRP, $(\mathrm{p}=<0.001)(\mathrm{r}=0.75$, $0.73)$ respectively. And also there was negative correlation between IFN $\gamma$ and $\mathrm{Hb}$ $(\mathrm{p}=<0.001)(\mathrm{r}=0.80)$.

Table (1): Clinical and biochemical data for 30 patients with rheumatoid arthritis (group 1) and 10 control subject

\begin{tabular}{|c|c|c|}
\hline parameter & $\begin{array}{c}\text { Group I patients with RA } \\
\text { N=30 mean } \pm \text { SD }\end{array}$ & $\begin{array}{c}\text { Group II control } \\
\text { N=10 mean } \pm \text { SD }\end{array}$ \\
\hline Age (years) & $28.3 \pm 9.7$ & $31.1 \pm 9.7$ \\
\hline $\begin{array}{c}\text { Duration of disease } \\
\text { (years) }\end{array}$ & $5.2 \pm 2$ & \\
\hline $\begin{array}{c}\text { Morning stiff } \\
\text { (minuets) }\end{array}$ & $19 \pm 3.2$ & \\
\hline $\begin{array}{c}\text { Tender joint } \\
\text { Swollen joint count }\end{array}$ & $9.4 \pm 2$ & \\
\hline $\begin{array}{c}\text { AIS } \\
\text { Hemoglobin } \\
(\mathrm{g} / \mathrm{dl})\end{array}$ & $14.8 \pm 1.7$ & $12.5 \pm 4.7$ \\
\hline $\begin{array}{c}\mathrm{ESR} \\
(\mathrm{mm} / \mathrm{h})\end{array}$ & $10.5 \pm 1.1$ & $15 \pm 4$ \\
\hline $\begin{array}{c}\text { CRP } \\
(\mathrm{mg} / \mathrm{l})\end{array}$ & $60 \pm 30$ & $1.8 \pm 0.4$ \\
\hline $\begin{array}{c}\text { IL-10 } \\
(\mathrm{pg} / \mathrm{ml})\end{array}$ & $34.1 \pm 12.6$ & $2.27 \pm 0.3$ \\
\hline $\begin{array}{c}\text { IL-16 } \\
(\mathrm{pg} / \mathrm{ml})\end{array}$ & $27.9 \pm 5.6$ & $3.2 \pm 0.6$ \\
\hline $\begin{array}{c}\text { IFN- } \gamma \\
(\mathrm{pg} . / \mathrm{ml})\end{array}$ & $60.7 \pm 41.4$ & \\
\hline
\end{tabular}

Table 2:Mean values of laboratory variables in patients with RA(group I) as compared to control group (group II).

\begin{tabular}{|l|c|c|c|c|c|}
\hline parameter & $\begin{array}{c}\text { Group I } \\
\text { mean } \pm \text { SD }\end{array}$ & $\begin{array}{c}\text { Group II mean } \\
\pm \text { SD }\end{array}$ & P value & T value & significance \\
\hline $\begin{array}{l}\text { Hemoglobin } \\
(\mathrm{g} / \mathrm{dl})\end{array}$ & $10.5 \pm 1.1$ & $12.5 \pm 4.7$ & $<0.01$ & 7.9 & HS \\
\hline $\begin{array}{l}\text { ESR } \\
(\mathrm{mm} / \mathrm{h})\end{array}$ & $60 \pm 30$ & $15 \pm 4$ & $<0.01$ & 3.8 & HS \\
\hline $\begin{array}{l}\mathrm{CRP} \\
(\mathrm{mg} / \mathrm{l})\end{array}$ & $34.1 \pm 12.6$ & $1.8 \pm 0.4$ & $<0.01$ & 1 & HS \\
\hline $\begin{array}{l}\text { IL-10 } \\
(\mathrm{pg} / \mathrm{ml})\end{array}$ & $27.9 \pm 5.6$ & $2.27 \pm 0.3$ & $<0.01$ & 9.2 & HS \\
\hline $\begin{array}{l}\text { IL-16 } \\
(\mathrm{pg} / \mathrm{ml})\end{array}$ & $60.7 \pm 41.4$ & $3.2 \pm 0.6$ & $<0.01$ & 1.2 & HS \\
\hline $\begin{array}{l}\text { IFN- } \gamma \\
(\mathrm{pg} . / \mathrm{ml})\end{array}$ & $83.5 \pm 16.8$ & $12.6 \pm 2.8$ & $<0.01$ & 1.1 & HS \\
\hline
\end{tabular}


Table (3): Correlation between IL-10 and each hemoglobin level, erythrocyte sedimentation rate, $C$ reactive protein, $I L-16$, and IFN $\gamma$ in (group I) 30 patients with RA

\begin{tabular}{|c|c|c|c|c|}
\hline \multirow{4}{*}{$\begin{array}{c}\text { IL-10 } \\
(\mathrm{pg} . / \mathrm{ml})\end{array}$} & parameter & R value & P value & significance \\
\cline { 2 - 5 } & $\begin{array}{c}\text { Hemoglobin } \\
(\mathrm{g} / \mathrm{dl})\end{array}$ & -0.74 & HS \\
\cline { 2 - 5 } & $\begin{array}{c}\mathrm{ESR} \\
(\mathrm{mm} / \mathrm{h})\end{array}$ & 0.67 & $<0.001$ & HS \\
\cline { 2 - 5 } & $\begin{array}{c}\mathrm{CRP} \\
(\mathrm{mg} / \mathrm{l})\end{array}$ & 0.71 & HS \\
\cline { 2 - 5 } & $\begin{array}{c}\mathrm{IL}-16 \\
(\mathrm{pg} / \mathrm{ml})\end{array}$ & 0.63 & $<0.001$ & HS \\
\cline { 2 - 5 } & $\begin{array}{c}\text { IFN- } \gamma \\
(\mathrm{pg} . / \mathrm{ml})\end{array}$ & 0.55 & $<0.001$ & HS \\
\hline
\end{tabular}

Table 4): Correlation between IL-16and each of hemoglobin level, erythrocyte sedimentation rate, $\mathrm{C}$ reactive protein, and IFN $\gamma$ in 30 patients (group I) with $\mathrm{RA}$

\begin{tabular}{|c|c|c|c|c|}
\hline \multirow{4}{*}{$\begin{array}{c}\text { IL-16 } \\
\text { (pg./ ml })\end{array}$} & parameter & R value & P value & significance \\
\cline { 2 - 5 } & $\begin{array}{c}\text { Hemoglobin } \\
(\mathrm{g} / \mathrm{dl})\end{array}$ & -0.89 & $<0.001$ & HS \\
\cline { 2 - 5 } & $\begin{array}{c}\text { ESR } \\
(\mathrm{mm} / \mathrm{h})\end{array}$ & 0.87 & $<0.001$ & HS \\
\cline { 2 - 5 } & $\begin{array}{c}\mathrm{CRP} \\
(\mathrm{mg} / \mathrm{l})\end{array}$ & 0.83 & $<0.001$ & HS \\
\cline { 2 - 5 } & $\begin{array}{c}\text { IFN- } \gamma \\
(\mathrm{pg} . / \mathrm{ml})\end{array}$ & 0.89 & $<0.001$ & HS \\
\hline
\end{tabular}

Table (5): Correlation between IFN $\gamma$ and each hemoglobin level, erythrocyte sedimentation rate, $C$ reactive protein in (group I) 30 patients with $R A$

\begin{tabular}{|l|c|c|c|c|}
\hline & parameter & R value & P value & significance \\
\cline { 2 - 5 } & $\begin{array}{c}\text { Hemoglobin } \\
(\mathrm{g} / \mathrm{dl})\end{array}$ & -0.80 & $<0.001$ & HS \\
\cline { 2 - 5 } & $\begin{array}{c}\text { ESR } \\
(\mathrm{mm} / \mathrm{h})\end{array}$ & 0.75 & $<0.001$ & HS \\
\cline { 2 - 5 }$(\mathrm{pg} . / \mathrm{ml})$ & $\begin{array}{c}\mathrm{CRP} \\
(\mathrm{mg} / \mathrm{l})\end{array}$ & 0.73 & $<0.001$ & HS \\
\hline
\end{tabular}




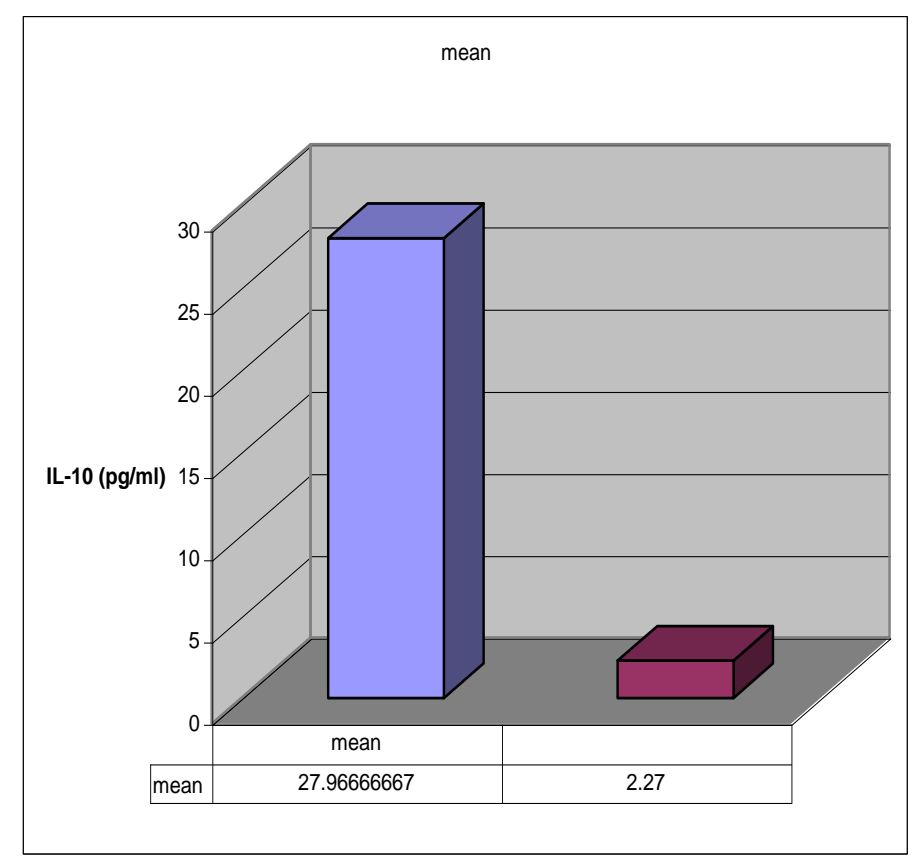

Fig(1) Mean values of IL-10 in rheumatoid arthritis group and control group

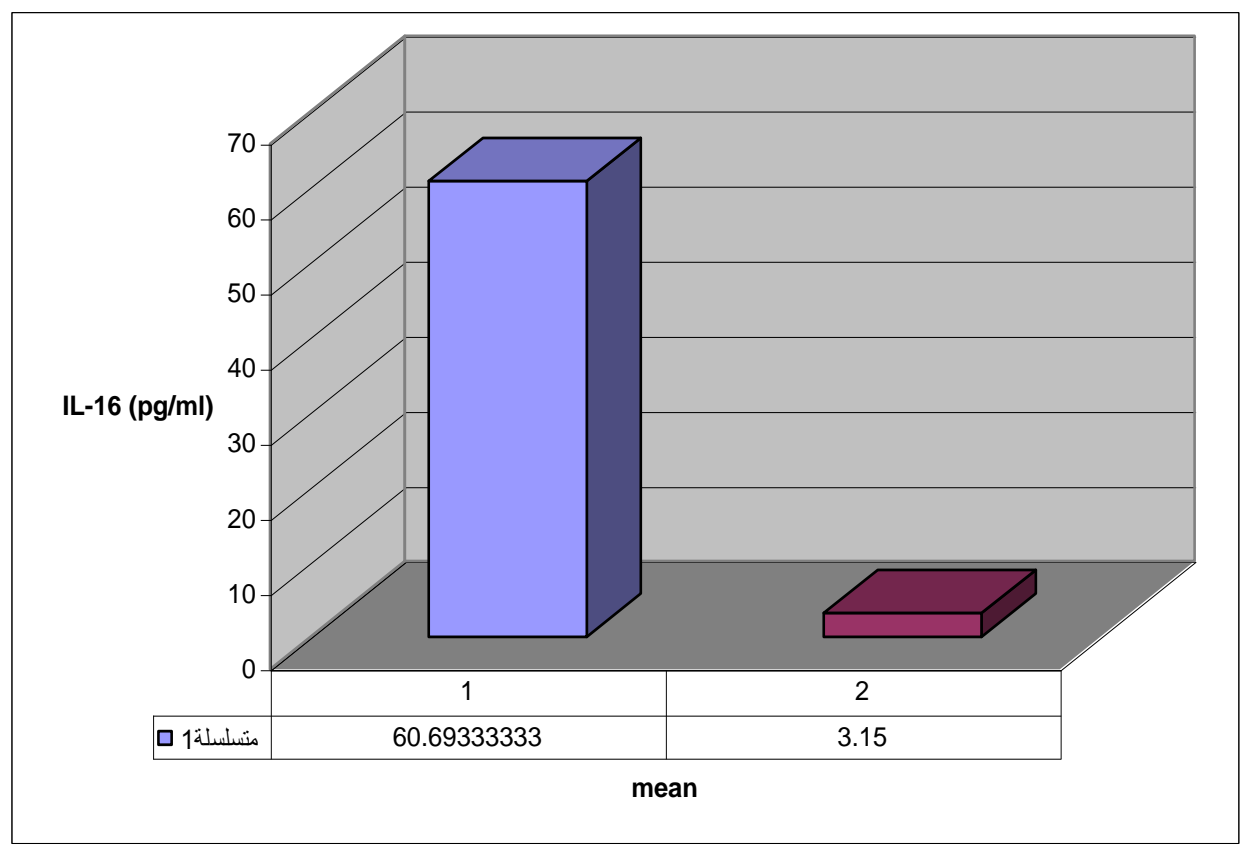

Fig (2) Mean values of IL-16 in patients with rheumatoid arthritis and control group. 
Interleukin-10, Interleukin- 16 and Interferon- $\gamma \ldots \ldots . .$.

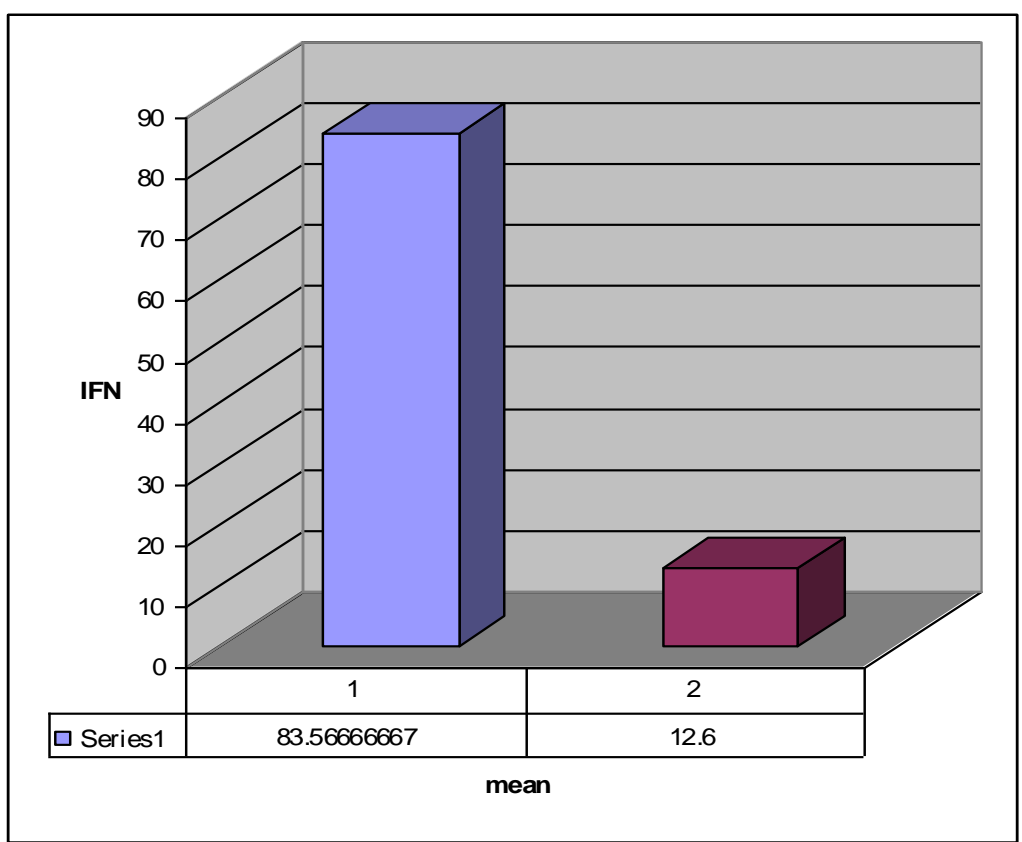

Fig (3) Mean values of IFN $\gamma$ in patients with rheumatoid arthritis and control group

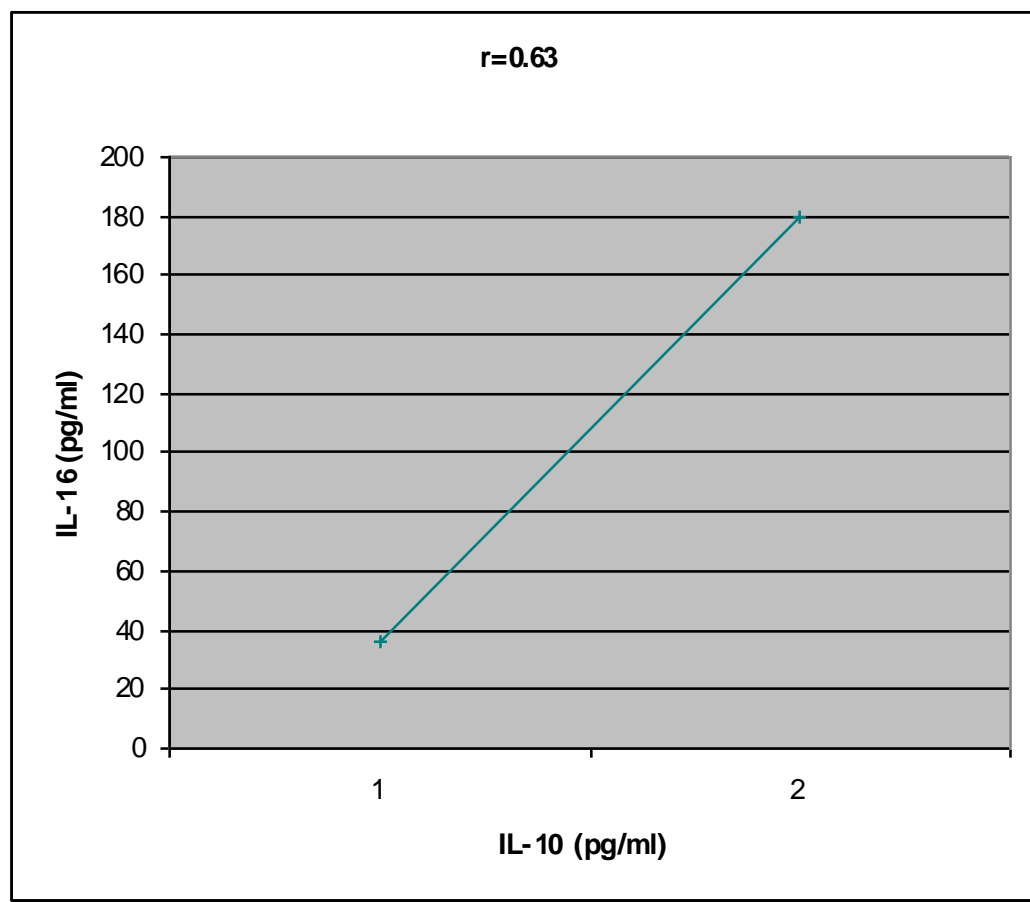

Fig (4) Positive correlation between IL-10 and IL-16 among group 1 


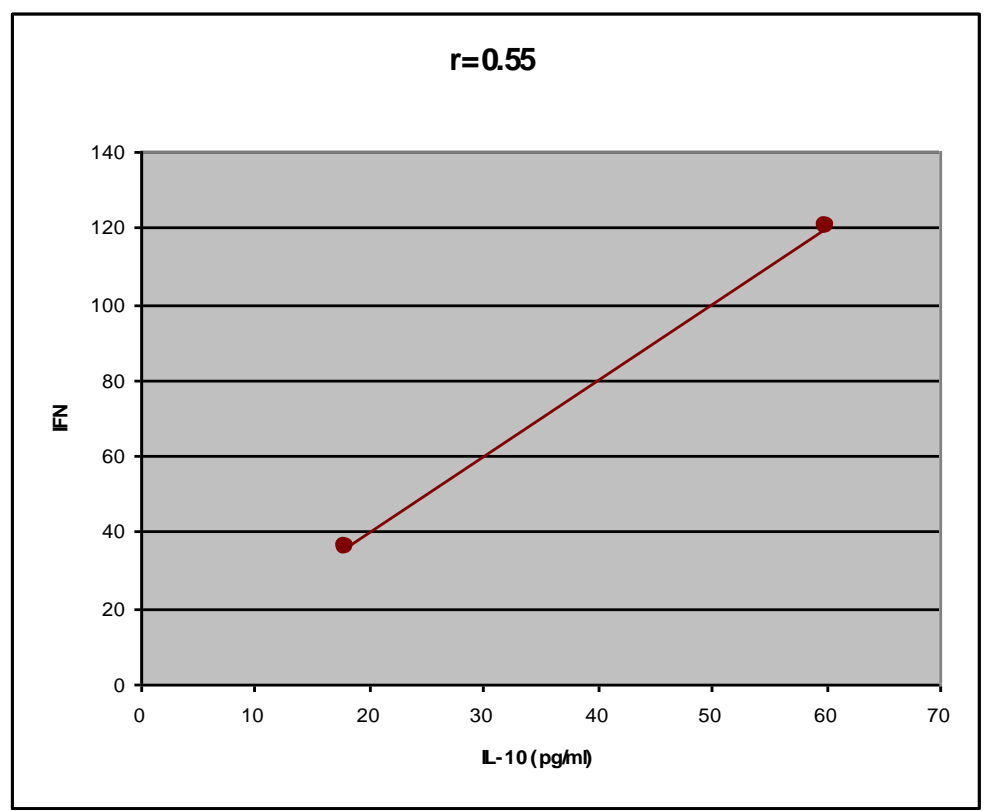

Fig (5) Positive correlation between IL-10 and IFN $\gamma$ among group 1

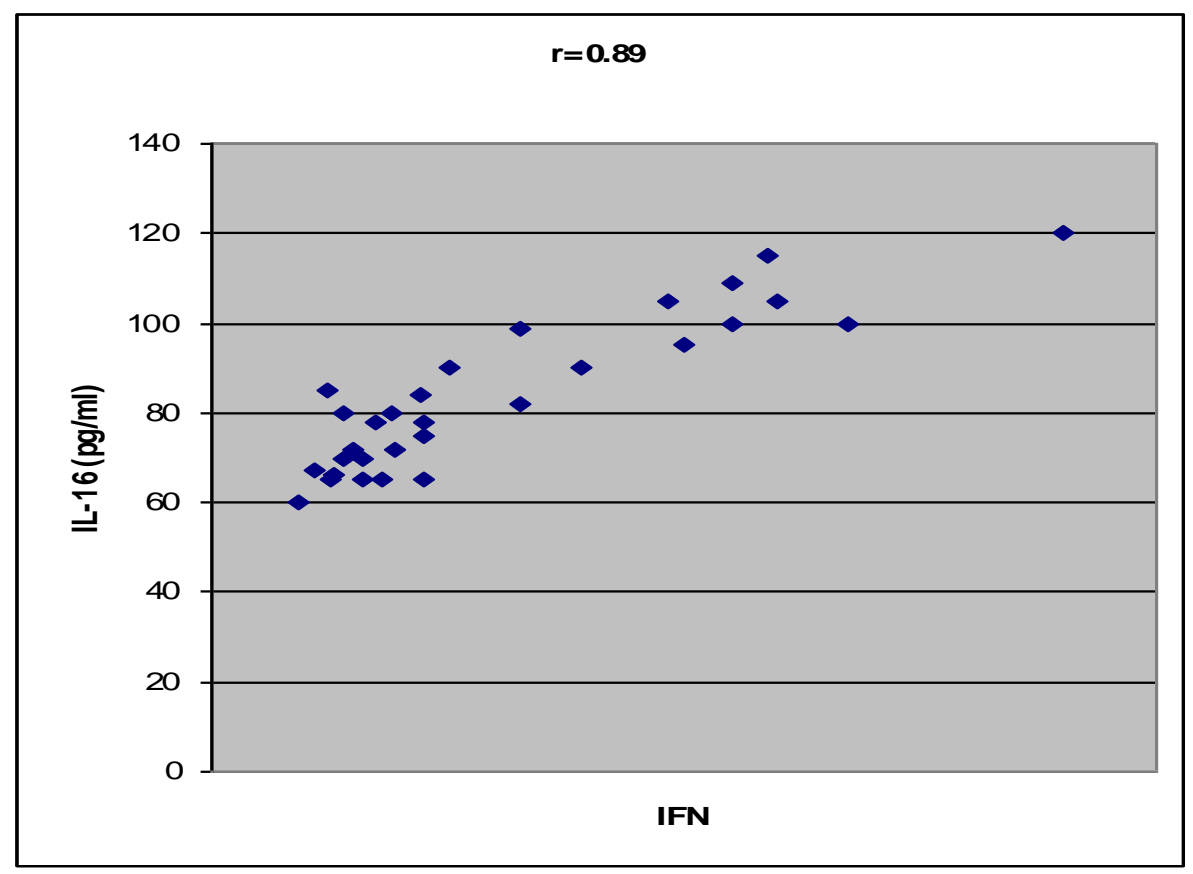

Fig (6) Positive correlation between IL-16 and IFN $\gamma$ among group 1 


\section{Discussion}

Arthritis and joint destruction are the hallmarks of rheumatoid arthritis (RA). The progression of joint destruction varies considerably among patients with RA (Huizinga et al; 2000).

Proinflammatory cytokines play a significant pathogenic role in RA. Antiinflammatory cytokines can also be found in the affected joints and it has been postulated that chronic synovitis may reflect an imbalance in pro- and antiinflammatory cytokine production in RA (Weckmann et al; 1996). Consequently, the potential effect of anti-inflammatory cytokines such as IL-10 in RA is of great interest (Mackay et al; 2003).

Various lines of research suggest an important role of IL-10 in the pathogenesis of joint destruction in RA. Other studies show that IL-10 inhibits the generation of proinflammatory cytokines and the proliferation of Th1 lymphocytes.

IL-16 is a $\mathrm{T}$ cell derived cytokine originally identified and purified as lymphocyte chemoattractant factor.IL-16 acts via the CD4 molecule as its receptor and exert a broad spectrum of both pro- and anti-inflammatory biologic activities (Blaschke et al; 2001).

Interferon- gamma (IFN- $\gamma$ ) is a secretary product of activated T-cell of the Th1 subset and natural killer cells (NK). INF- $\gamma$ is produced in response to specific and non-specific immunologic activation of lymphocyte, usually T-lymphocytes (Boehm et al; 1997).

In the present study plasma level of IL-10, IL-16, and IFN- $\gamma$ were measured in 30 patients with rheumatoid arthritis compared to 10 sex and age matched normal subjects.

Our results show highly significant increase in serum IL-10 in patients with RA compared to control group. Our results agree with Cush et al; (1995) who found serum and synovial fluid (SF) contained significantly elevated IL-10 level compared to control group. On other hand Verhoef et al; (2001) found IL-10 production was statistically higher in patients group with mild disease compared to severe disease.

Also our results show highly significant positive correlation between serum IL-10 and each of ESR, CRP.This result disagree with Cush et al;( 1995 ) who found no correlation was demonstrated between IL-10 levels and most clinical measures of disease activity (age, disease duration, morning stiffness, patients and physician global assessment, swollen or tender joint counts. Also they reported no significant difference was noted between those patients treated or not treated with prednisone. But Verhoef et al; (2001) found negative correlations between IL-10 production and ESR, CRP, and strong negative correlation with radiographic joint damage as well as progression of joint damage.

In the present study serum level of IL10 show highly significant correlation with each serum level of IL-16 and IFN $\gamma$, this results show disagreements with the results of Verhoef et al; (2001) they reported no correlation between IL-10 and IFN $\gamma$.

Lard et al; (2003) reported that IL- 10 genotype was not associated with the incidence of RA, but instead ,correlated with disease progression, as determined by extent of joint destruction.

Our results show highly significant increase in serum IL-16 in patients with RA compared to control group. And also show highly significant positive correlation between serum IL-16 and each of ESR, CRP.

Our data show agreements with that of Blaschke et al; (2001) who detect that IL-16 was significantly high in sera and synovial fluid of patients with RA in comparison to osteoarthritis and to normal control, also they reported the lack of significant correlation between IL-16 expression, clinical disease activity, and local inflammatory activity suggesting a regulatory rather a pro-inflammatory function for IL-16 in the pathogenesis of chronic synovial inflammation in RA.

These finding for IL-16 differ from cytokines with predominant proinflam- 
matory activity in RA, such as TNF- $\alpha$, IL1B, and IL-6, also OKamoto et al; ( 1997) have described increased serum levels of these macrophage derived cytokines and significant correlation between serum cytokine concentration and disease activity in RA.

Kaufmann et al; ( 2001) found serum level of IL-16 in RA was increased significantly compared with non RA control, and in RA patients and controls, there were no significant differences in cytokine level with respect to age and sex. And also they reported that a level of IL-16 was correlated with ESR and C-reactive protein.

Our results show highly significant increase in serum IFN $\gamma$ in patients with RA compared to control group. And also show highly significant positive correlation between serum IFN $\gamma$ and each of ESR, CRP.

This result agree with Kanik et al; (1998) who found increased production of IFN $\gamma$ in RA patients with new onset synovitis, in contrast to patients with chronic RA who had increased IL-16 production.

Verhoef et al; (2001) reported no correlation between IFN $\gamma$ with disease activity variables (ESR, CRP) or joint damage and that may be due to use of medication, and also found negative correlation between IFN $\gamma$ and age of RA patients.

Scola et al; (2002) found that juvenile RA (JRA) has generally been described as a type I disease with increased level of IFN $\gamma$ and variably low IL-4 in study utilizing synovial fluid, and also confirm continued expression of IFN $\gamma / \mathrm{IL}-4$ ratio compared to that of control tissue, but also they reported no significant difference in the expression of IL-10 in JRA from that controls, possibly indicating a loss of regulation in severe or long standing disease.

Bas et al; (2003) found SF concentrations of IL-10 were significantly lower in patients with reactive arthritis than RA patients. The SF level of IFN $\gamma$ was not significantly different but the ratios of IFN $\gamma$ to IL-10 were significantly higher in patients with reactive arthritis.

\section{Conclusion}

These data suggest that there is increased production of IL-10, IL-16, and
IFN- $\gamma$ in patients with rheumatoid arthritis, and that is correlated with disease activity. These cytokines are interesting for further research and novel therapeutic approach in this inflammatory disease.

\section{References}

1. Arnett, F.C; Edworthy, S.M;Bloch, D.A; McShare, D.J; et al. (1988): The American Rheumatism Association 1987 revised criteria for the classification of Rheumatoid arthritis. Arthritis Rheum 31:315-324

2. Bas, S; Kvien, T.K; Buchs, N; Fulpius, T; Gabay, C.(2003): Lower level of synovial fluid interferon- $\gamma$ in HLA-B27-positive than in HLA-B27-negative patients with Chlamydia trachomatis reactive arthritis. Rheumatology 42:461-467

3. Blaschke, S; Schulz, H; Schwarz, G; Blaschke, V;et al. (2001): Interleukin 16 Expression in relation to disease Activity in Rheumatoid Arthritis. The Journal of Rheumatology 28:1

4. Boehm, U; et al.(1997): Cellular responses to interferon gamma. Annu Rev Immunol 15:749.

5. Cush, J.J; Splawski, J.B; Thomas, R; McFarlin, J.E; et al. (1995): Elevated interleukin-10 levels in patients with rheumatoid arthritis. Arthritis Rheum 38:96-104.

6. Huizinga, T.W.J; Keijser, V; Yanni, G; Hall, M; et al. (2000): Are differences in interleukin 10 production associated with joint damage? Rheumatology 39:11801188.

7. Kanik, K.S; Hagiwara, E; Yarboro, C.H; Schumacher, H.R; et al. (1998): Distinct patterns of cytokine secretion characterizes new onset synovitis versus chronic Rheumatoid arthritis. The Journal of Rheumatology 25:16-22.

8. Kaufmann, J; Franke, S; Kintsch-Engel, R; et al. (2001): Correlation of circulating interleukin 16 with proinflammatory cytokines in patients with rheumatoid arthritis. Rheumatology 40:474-475.

9. Lard, L. R; Gaalen, F .A; Schonkeren, J .J; Pieterman, E. J; et al. (2003): Association of the -2849 Interleukin -10 promoter polymorphism with autoantibody production and joint destruction in rheumatoid arthritis. Arthritis \& Rheum vol.48, No7, July, pp 1841:48. 
10. Libula, R; Singer, S; and Mcvecitt, $M$. (1995): Th1 and Th2 CD4+ T cell in the pathogenesis of organ specific autoimmune disease. Immunology Today 16:32-36.

11. Littman,B.H; Drury, C.E; Zimmerer, R.O; Stack, C.B; Law, C.G. (1995): Rheumatoid arthritis treated with tenidap and piroxicam. Clinical associations with cytokine modulation by tenidap. Arthritis Rheum 38: 29-37.

12. Mackay, K; Milicic, A; Lee, D; Tikly, M ;et al. (2003): Rheumatoid arthritis susceptibility and interleukin 10 : a study of two ethnically diverse populations. Rheumatology 42:149-153.

13. Moller, B; Paulukat, G; Nold, M; Behrens, M;et al. (2003): Interferon- $\gamma$ induces expression of interleukin-18 binding protein in fibroblast- like synoviocytes. Rheumatology 42:442-445.

14. Oberholzer, A; Oberholzer, C; and Moldamer, L. (2002): IL-10: A complex role in the pathogenesis of sepsis syndromes and its potential as an anti-inflammatory drug. Crit. Care. Med 301 (supp 11):558-563.

15. Okamoto, H; Yamamura, M; Morita, Y; Harada, S; et al. (1997): The synovial expression and serum levels of interleukin6, interleukin-11, leukemia inhibitory factor, and oncostatin $\mathrm{M}$ in Rheumatoid arthritis. Arthritis Rheum 40:1096-105.
16. Panayi, G.S; Lanchbury, J.S; Kingsley, G.H. (1992): The importance of the T cell in initiating and maintaining the chronic synovitis of rheumatoid arthritis. Arthritis Rheum 35:729-35.

17. Reparon-Schuijt, C.C; van Esch, W.J.E; van Kooten,M; et al. (2001): Secretion of ant-citrulline-containing peptide antibody by B lymphocytes in rheumatoid arthritis. Arthritis Rheum 44:41-7.

18. Reparon-Schuijt, C.C; van Esch, W.J.E; van Kooten,M; Levarht, E.W.N; et al. (1998): Functional analysis of rheumatoid factor-producing B cells from the synovial fluid of rheumatoid arthritis patients. Arthritis Rheum 41:2211-20.

19. Scola, M.P; Thompson, S.D; Brunner, H.I; et al. (2002): Interferon- $\gamma$ : Interleukin 4 Ratios and Associated Type 1 Cytokine Expression in Juvenile Rheumatoid Arthritis Synovial Tissue. The Journal of Rheumatology 29:369-78.

20. Verhoef, C.M; van Roon, J.A.G; Vianen, M.A, et al. (2001): Interleukin-10, Not IL4 or Interferon- $\gamma$ Production, Correlates with Progression of Joint Destruction in Rheumatoid Arthritis. The Journal of Rheumatology 28:1960-6.

21. Weckmann, A.L; Alcocer-Varela, J; et al.(1996): Cytokine inhibitors in autoimmune disease. Semin Arthritis Rheum 26: 539-57. 


\section{انترليوكين 10 و انترليوكين 16و انترفيرون جاما في مرض الرثيان المفصلي}

\section{وعلاقتها بالنشاط المرضى بهي}

إيمان محمد عبد الرحمن*، حمدية عزت*** ، مها محمد عبد المحسن***،كريمة

$$
\text { يوسف * يون: }
$$

قسم الباطنة العامة**، الباتولوجيا الاكلنيكية***، كلية طب بنات جامعة الأزهر

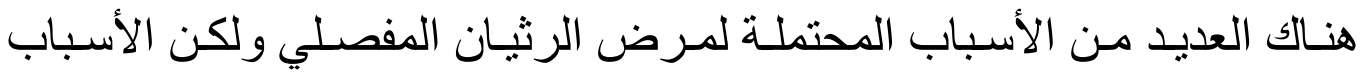

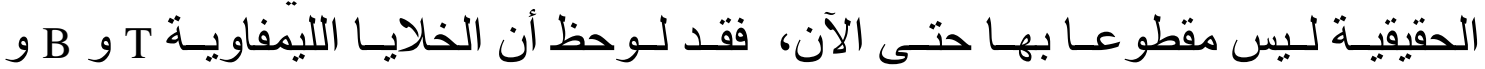

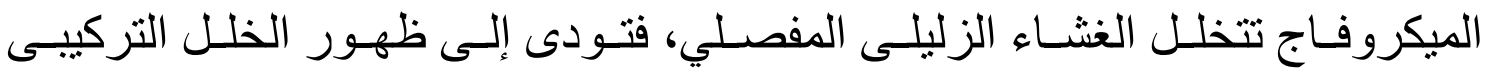

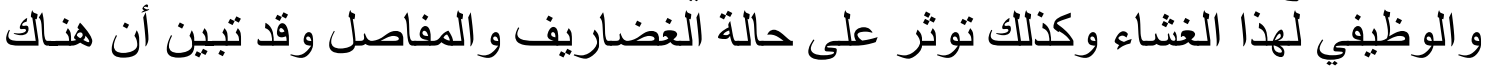

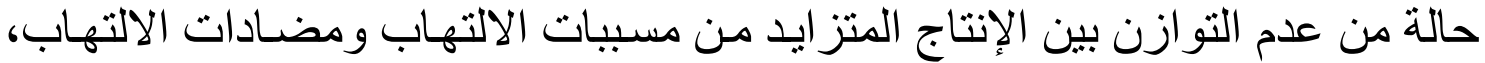

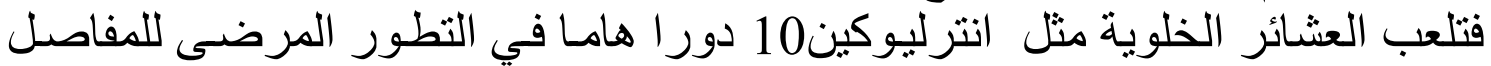
وكذلك التأثير على الجهاز المناعي.

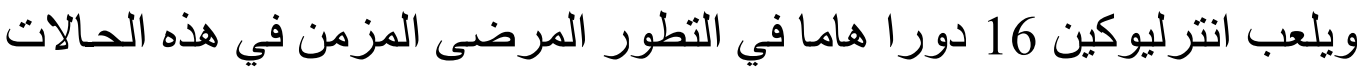

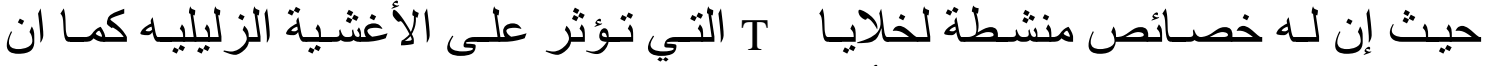
انترفيورن جاما يلعب دور ا منشطا أيضا على خلايا T المساعدة.

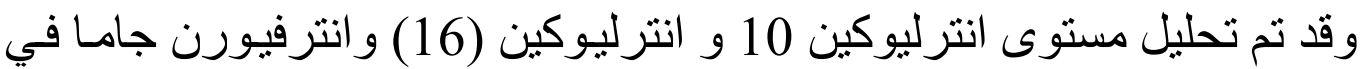

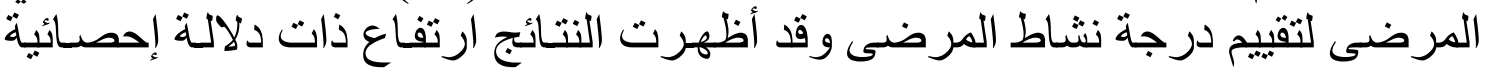

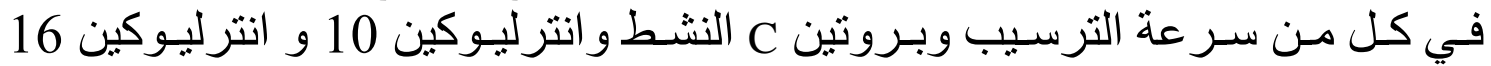

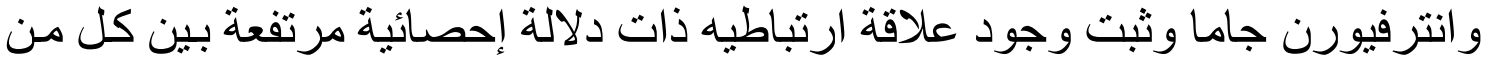

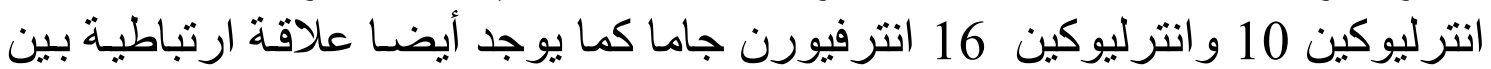

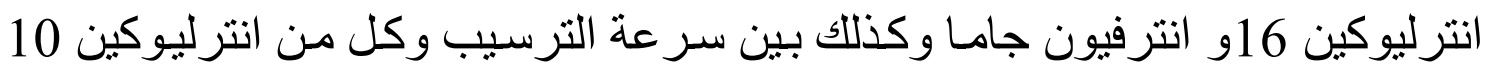
و وانترلوكين 16 و انترفيون جاما.

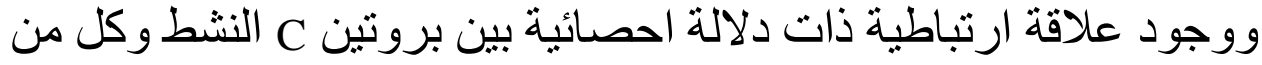

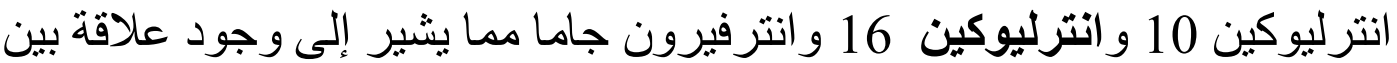
ارتفاع مستوى العثائر الخلوية ودرجة نثاط المرض. 